\title{
Protein Misfolding during Pregnancy: New Approaches to Preeclampsia Diagnostics
}

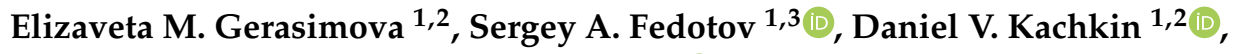 \\ Elena S. Vashukova ${ }^{4}$, Andrey S. Glotov ${ }^{4,5}$, Yury O. Chernoff ${ }^{1,6}$ and Aleksandr A. Rubel ${ }^{1,2, * \mathbb{C}}$ \\ 1 Laboratory of Amyloid Biology, St. Petersburg State University, 199034 St. Petersburg, Russia; \\ elelovaya@gmail.com (E.M.G.); serg900@yandex.ru (S.A.F.); pspdaniel@mail.ru (D.V.K); \\ yury.chernoff@biology.gatech.edu (Y.O.C.) \\ 2 Department of Genetics and Biotechnology, St. Petersburg State University, 199034 St. Petersburg, Russia \\ 3 Pavlov Institute of Physiology, Russian Academy of Sciences, 199034 St. Petersburg, Russia \\ 4 Department of Genomic Medicine, D.O. Ott Research Institute of Obstetrics, Gynecology and \\ Reproductology, 199034 St. Petersburg, Russia; vi_lena@list.ru (E.S.V.); anglotov@mail.ru (A.S.G.) \\ 5 Laboratory of Biobanking and Genomic Medicine, Institute of Translation Biomedicine, St. Petersburg \\ State University, 199034 St. Petersburg, Russia \\ 6 School of Biological Sciences, Georgia Institute of Technology, Atlanta, GA 30332, USA \\ * Correspondence: a.rubel@spbu.ru; Tel.: +7-911-970-66-47
}

Received: 6 November 2019; Accepted: 4 December 2019; Published: 7 December 2019

\begin{abstract}
Preeclampsia (PE) is a multisystem heterogeneous complication of pregnancy remaining a leading cause of maternal and perinatal morbidity and mortality over the world. PE has a large spectrum of clinical features and symptoms, which make diagnosis challenging. Despite a long period of studying, PE etiology is still unclear and there are no reliable rapid tests for early diagnosis of this disease. During the last decade, it was shown that proteins misfolding and aggregation are associated with PE. Several proteins, including amyloid beta peptide, transthyretin, alpha-1 antitrypsin, albumin, IgG k-free light chains, and ceruloplasmin are dysregulated in PE, resulting in toxic deposition of amyloid-like aggregates in the placenta and body fluids. It is also possible that aggregated proteins induce defective trophoblast invasion, placental ischemia, ER stress, and promote PE manifestation. The fact that protein aggregation is an emerging biomarker of PE provides an opportunity to develop new diagnostic approaches based on amyloids special features, such as Congo red (CR) staining and thioflavin T (ThT) enhanced fluorescence.
\end{abstract}

Keywords: preeclampsia; amyloid; protein misfolding; diagnostic; etiology

\section{Introduction}

Preeclampsia (PE) is the human-specific pregnancy complication leading contributor to maternal and fetal mortality worldwide [1]. The clinical symptoms appear after 20 weeks of gestation and include new-onset hypertension, proteinuria, edema, and maternal organ dysfunction [2-4]. However, it can be difficult to distinguish PE from other pathologies that are also characterized by hypertension and proteinuria, such as chronic hypertension or glomerulonephropathy.

If left untreated, PE can progress to eclampsia, which is characterized by stroke, seizures, kidney damage, cerebrovascular accidents, microangiopathic hemolytic anemia, liver failure, pulmonary edema-all of these serious consequences of PE can result in maternal death $[5,6]$. The only effective treatment is the delivery of the placenta and the fetus, leading to iatrogenic prematurity [7]. This is the reason why early diagnosis is so important.

To date, a few promising biomarkers for PE prediction have been found, used alone or in combination [8,9]. They include: a) biochemical markers, such as levels of the placental growth factor 
(PIGF) [10], of soluble Fms-like tyrosine kinase 1 (sFlt-1) [11,12], and the sFlt-1/P1GF ratio [13], as well as levels of the placental protein 13 (PP13) [14,15], soluble endoglin (sEng) [16,17], pregnancy-associated plasma protein A (PAPP-A) [18], and some others; and b) physiological and biophysical markers, such as mean arterial pressure and uterine artery pulsatility index $[9,19]$. However, non-invasive and express methods (especially for early diagnosis or prediction of $\mathrm{PE}$ ), which would not require sophisticated equipment and complex biochemical tests and would allow preventing or starting timely and effective treatment PE before the clinical manifestation of the disease, are still lacking.

Recent studies have shown that proteins misfolding and aggregation is associated with PE. Several proteins, including amyloid beta-peptide, alpha- 1 antitrypsin, albumin, IgG k-free light chains, and ceruloplasmin, are dysregulated in PE resulting in deposition of amyloid-like aggregates in the placenta and body fluids. These facts provide an opportunity to develop new diagnostic approaches owing to amyloid have special features.

This review discusses recent findings about proteins misfolding and aggregation during PE and possible diagnostic methods based on these phenomena.

\section{Diagnosis of PE}

Traditionally applied diagnostic criteria of PE are hypertension, appearing after 20 weeks of gestation, combined with proteinuria, that is, the concentration of total protein at the level of $300 \mathrm{mg}$ or higher in a $24 \mathrm{~h}$ urine sample [20]. Hypertension is defined as either a systolic blood pressure at the level above $140 \mathrm{~mm} \mathrm{Hg}$, or a diastolic blood pressure (BP) at the level higher than $90 \mathrm{~mm} \mathrm{Hg}$, as detected at least at two separate occasions. If blood pressure is severe (systolic BP $\geq 160$ and/or diastolic $\mathrm{BP} \geq 110 \mathrm{~mm} \mathrm{Hg}$ ), the measurement should be repeated after $15 \mathrm{~min}$; for less severe blood pressure, repeated measurement should be taken after 3-6 $\mathrm{h}$ [4].

However, according to the recommendations of the International Society for the Study of Hypertension in Pregnancy [3], and American College of Obstetricians and Gynecologists [2], proteinuria is not a necessary feature of PE. Rather, PE is diagnosed by the presence of new onset hypertension accompanied by proteinuria and/or renal insufficiency, pulmonary edema, liver involvement, hemolysis, or thrombocytopenia, neurological complications, or fetal growth restriction [21]. The reason for excluding proteinuria as a required criterion is that PE can occur before glomerular capillary endotheliosis becomes severe enough to produce proteinuria [22]. In addition, the standard cut-off for protein concentrations remains uncertain, as the typically used cut-off level of $300 \mathrm{mg}$ per $24 \mathrm{~h}$ in urine could be too high $[23,24]$. Moreover, the urinary dipstick analysis, which is usually used in medical practice, demonstrates a large number of false positive results $[25,26]$, owing to variations in protein excretion, patient diet, and time of urine sampling [24].

Hence, PE is considered a multisystemic disease with non-specific clinical features. The appearance of symptoms such as proteinuria, hypertension, liver failure, and others does not necessarily guarantee a diagnosis of PE. This uncertainty leads to serious issues, as PE requires mandatory delivery. Lack of the rapid, specific, and non-invasive method distinguishing PE from other pregnancy complications and assuring a reliable diagnosis within a short time period is a major challenge for PE research and treatment.

\section{Etiology and Pathogenesis of PE}

Despite numerous studies, the etiology and pathogenesis of PE are still poorly understood. The speed of PE progression is unpredictable, and the subclinical phase is long. This may lead to fetal damage and adaptive clinical manifestations, such as thrombocytopenia, oxidative stress, vascular endothelial dysfunction, systemic inflammation, altered levels of nitric oxide, and aberrant angiogenesis [27]. The central role in the pathogenesis of PE is signified by the observation that the effective treatment for this complication of pregnancy is the early delivery of the fetus and the placenta [28]. 
In addition, PE is a multifactorial complication of pregnancy including various subclasses. Traditionally, PE is divided into placental or early-onset PE ( $<34$ weeks), and maternal or late-onset PE ( $\geq 34$ weeks), according to gestational age at diagnosis or delivery $[29,30]$. These two subtypes seem to have different etiologies. In early-onset $\mathrm{PE}$, abnormal placentation under hypoxic conditions with higher levels of sFlt-1 and lower levels of PIGF take place [31]. Late-onset PE seems to occur from the interaction between a presumably normal placenta and maternal factors and to be a decompensated response to the oxidase stress in the placenta by a dysfunctional maternal endothelium (one aspect of a systemic maternal inflammatory response) [32]. In addition, PE cases can also be divided into subclasses according to their severity [33]. However, these classifications still do not fully reflect the heterogeneity observed in this complication of pregnancy.

Recently, systems biology approaches identified at least three forms of PE based on placental transcriptional phenotyping by using aggregate analysis on previously published PE microarray datasets and clustering the samples based on gene expression [34,35]. The first of these subclasses may arise if the mother demonstrates cardiovascular risk factors resulting in a poor maternal response to pregnancy and development of a later-onset, less severe form of PE (so called "maternal" PE), while the fetus will likely still be normal.

Another "immunological" subclass of PE seems to depend on the presence of immunological risk factors and occur because of incompatibility between the mother and the fetus, which may evoke an immune rejection of the placenta and an immunological presentation of PE.

Finally, the third or "canonical" PE form demonstrates placental dysfunction, elevated expression of known PE markers, and genes associated with poor oxygenation. The traditional view of the pathogenetic mechanisms involved in "canonical" PE is that genetic and environmental factors contribute to the defective deep placentation. Subsequently, the ischemic placenta releases soluble factors into the maternal circulation, which are responsible for the clinical manifestations of the disease [36].

The central hypothesis explaining PE occurrence relates it to the defective trophoblastic invasion with associated uteroplacental hypoperfusion [37]. During normal pregnancy, blood flow in the uterus increases to enable perfusion of the intervillous space of the placenta and to support the growth of the fetus. Physiological transformation of the spiral arteries of the uterus, a process in which trophoblasts invade the uterus and transform the arteries from narrow-diameter to large-diameter vessels, provides the increased blood flow and adequate placenta perfusion [38]. In PE, this remodeling is impaired, the placenta is likely to be deprived of oxygen, which is thought to explain the placental ischemia [39], increased oxidative stress in placenta, and overexpression of soluble fms-like tyrosine kinase-1 (sFlt-1) and soluble Endoglin (sEng) [40,41]. Interestingly, recent systems biology study has shifted the paradigm and shown that maternal inflammation can precede defective trophoblast invasion and shallow placentation [42]. Preexisting maternal diseases or perturbed maternal-fetal-placental immune interactions may be detected in PE earlier and upstream of placental dysfunction, not only downstream, as described before [42].

Several weeks before the appearance of PE clinical manifestations, levels of sFlt-1 and sEng are increased in the serum, and this increase exhibits a positive correlation with the disease severity [40]. sFlt-1 binds to vascular endothelial growth factor (VEGF), which is especially important for maintaining endothelial cell function in the fenestrated endothelium of the brain, liver, and renal glomerulus, and placental growth factor (PIGF), antagonizing their binding to the cell surface. High sFlt-1 and low VEGF/PIGF status contribute to the development of hypertension [43]. A similar effect on VEGF and PIGF is modulated by sVEGFR-1 (a soluble receptor of vascular endothelial growth factors). In recent years, compelling evidence has been collected to support the concept that sVEGFR-1 plays a significant role in the pathogenesis of PE, because of its inhibitory influence on VEGF and PIGF [12,44]. Serum sFlt-1/PlGF ratio has proven to be clinically useful for routine PE diagnosis $[10,45,46]$. Also, it should be said that automated assays for sFlt- 1 and PIGF measurements in serum, plasma, or urine have been already developed [10]. 
If myometrial segment of the spiral arteries during pregnancy was remodeled deficiently, it can lead to intermittent hypoxia and reoxygenation, which causes oxidative stress [47]. In addition, oxidative stress can occur in a result of the increased placental mitochondrial activity and production of reactive oxygen species (ROS), overwhelming the antioxidation defense mechanisms [48]. Increased levels of ROS, which are usually observed in PE, can lead to lipid peroxidation, protein carboxylation [47], releasing of proinflammatory cytokines and chemokines in blood flow [49], and DNA oxidation. All of these processes promote deterioration of the maternal organism [48].

Placental ischemia in PE is associated with a decreased expression of anti-oxidant heme oxygenase (HO) [50], and this contributes to the increased oxidative stress and the formation of micro-emboli [51]. The HO enzyme exists in two forms, Hmox1, and Hmox2, and converts free heme, which is a source of free radicals, first into biliverdin and then into bilirubin [52]. Hmox is upregulated in hypoxia and ischemia and it produces carbon monoxide, which acts as a vasodilator and decreases perfusion pressure in the placenta [53]. Indeed, increased gene expression of Hmox decreases circulating levels of sFlt-1 [54] and leads to normal pregnancy. Furthermore, trophoblasts express Hmox during pregnancy, and it was shown that inhibition of Hmox results in defective trophoblast invasion in vitro [55]. It has been proposed that pharmacological induction of Hmox expression could relieve hypertension and reduce serum concentrations of sVEGFR- 1 and oxidative stress in rodent models [56].

Thus, the imbalance between angiogenic and antiangiogenic factors leads to incomplete spiral artery remodeling, oxidative stress, placental ischemia, and releasing of soluble factors into the maternal bloodstream could contribute to clinical manifestations of PE. This view is confirmed by studies in which the injection of placental extracts of pregnant women with PE into guinea pigs elicited convulsions with liver and kidney involvement, similar to those observed in women with eclampsia [36].

However, the above-mentioned manifestations are not specific only to $\mathrm{PE}$, and errors in physiological remodeling of the spiral arteries per se are not sufficient to cause PE [57], as this failure has also been observed in other obstetric syndromes, such as preterm labor [58], spontaneous abortion, fetal death, and placental abruption [59]. In addition, it should be mentioned that mechanisms responsible for the failure of the physiological transformation of the spiral arteries are not fully understood [36].

By using mRNA fingerprinting, increased levels of neurokinin $B(\mathrm{NkB})$ were identified as the promising marker (and potential causative agent) associated with PE [60]. Indeed, significantly higher levels of $\mathrm{NkB}$ in the maternal and umbilical cord blood were observed in preeclampsia, compared to pregnancies without complications [61]. The advantage of excess NkB as a biomarker is its specificity, as elevated levels of NkB are not associated with other known hypertensive disorders [62]. It has been suggested that the defective trophoblast invasion observed in PE leads to placental ischemia and the potential release of $\mathrm{NkB}$ as a signal for the maternal organism to increase blood flow to the placenta. $\mathrm{NkB}$ acts as a dilatator in the vascular system of the placenta [63]. In addition, NkB is considered as an anti-angiogenic factor that inhibits the assembly of the vascular network of endothelial cells and angiogenesis [64]. NkB can also suppress the expression of some proteins, modulate implantation, and involve in the cellular response to hypoxia and oxidative stress [65]. Trophoblast hypoxia has been shown to stimulate the production of several proteins that are known targets of NkB suppression [66]. It is possible that excess $\mathrm{NkB}$ inhibits the normal cellular response to hypoxia and thus contributes to the development of PE [67]. Excess NkB could also be linked to additional clinical manifestations of PE such as thrombocytopenia, inflammation, edema, and eventually, eclampsia [65].

Systemic inflammation and overexpression of toll-like receptor 4 [43,68], as well as high levels of the heat shock protein Hsp70 in the serum [69], production of serum autoantibodies to angiotensin II receptor 1 (AT1-AA), and increased sensitivity to the effects of angiotensin II [70] were also linked to $\mathrm{PE}$, however most of these traits are either not sufficiently specific or technically difficult to diagnose.

An attractive concept postulates that endothelial cell activation and/or dysfunction can be a central feature of PE [36] as vasospasm, a condition in which dysfunctional endothelium releases smaller amounts of prostacyclin and nitric oxide compared to normal and cannot induce relaxation on smooth 
muscle cells, leading to a reduction in the diameter of the cerebral artery lumen, an arterial spasm, tissue ischemia, and necrosis, is a key component of this disorder, and the PE-associated proteinuria could result from the damage to the fenestrated glomerular endothelium. Indeed, levels of E-selectin and vascular cell adhesion protein 1 were higher in patients with PE than in healthy pregnant women [71], however overexpression of E-selectin is also observed in other obstetric syndromes [72].

The role of apolipoprotein E (ApoE) polymorphism in PE was proposed based on PE-like features, such as hypertension, proteinuria, and increased expression of sFlt-1, detected in the ApoE knockout mice $[73,74]$. Indeed, certain ApoE alleles are associated with dyslipidemia which may contribute to endothelial cell dysfunction. However, attempts to demonstrate a connection between PE and the particular allele combination of the APOR locus have failed thus far [74].

A novel and intriguing theory about PE pathogenesis is that PE is associated with protein misfolding and aggregation. At the very least, recent data implicate the high-ordered fibrous protein aggregates (amyloids) as a biomarker of PE.

\section{Protein Misfolding and Amyloid Aggregation in PE}

\subsection{Amyloids and Amyloidogenic Diseases}

More than 40 human diseases, including such neurodegenerative disorders as Alzheimer's, Parkinson's, and Huntington's diseases, and transmissible spongiform encephalopathies (TSEs), or prion diseases (such as Creutzfeldt-Jakob disease), are caused by protein misfolding, aggregation, and deposition of fibrous protein aggregates (amyloids) in tissues [75-82]. Examples of amyloidogenic proteins include amyloid $\beta$ peptide $(\mathrm{A} \beta)$ and tau in Alzheimer's disease [83-85], $\alpha$-synuclein in Parkinson's disease and related disorders [86,87], and prion protein (PrP) in Creutzfeldt-Jakob disease [88]. Amyloids are highly organized non-covalent cross- $\beta$ protein polymers that could accumulate in the form of fibrils of 7-10 $\mathrm{nm}$ in diameter and are highly resistant to anti-protein agents [76]. Mechanisms of amyloid-induced damage are not yet entirely clear (and could be different in different diseases). In many cases, amyloid formation interferes with the normal protein function, although a loss of protein function per se typically is not equivalent to the respective amyloid disease manifestations. Amyloids can immobilize protein of the same sequence, present in non-amyloid form, and thus spread via the process of nucleated polymerization. Transmissible amyloids, termed prions, can even spread between organisms, causing infection diseases such as TSEs. Recent data indicate that many disease-associated amyloids possess prion properties in specific conditions. Amyloid fibrils can be detected via binding to some dyes that recognize cross- $\beta$ assemblies. Examples of these dyes include a Congo red (CR) [89,90] and thioflavin T (ThT) [91-93]. Amyloids can also be detected by some amyloid-specific antibodies [94], and by electron microscopy (EM) $[95,96]$. Notably, the ability to form an amyloid is controlled by an amyloid protein itself, as confirmed by the observation that amyloids are formed by mammalian amyloidogenic proteins expressed in heterologous systems, such as yeast $[97,98]$.

\subsection{Amyloids in $P E$}

Recent studies have shown that misfolded proteins accumulate in the urine, serum, and the placenta of women with PE [99-104]. Indeed, proteins are vulnerable to misfolding because of changes in genetic and environmental factors [105] (Figure 1). Hence, protein structure can be destabilized under pressures, emerging as a normal part of pregnancy. Recent studies have proven that ischemia, hypoxia, and production of proinflammatory cytokines, associated with PE, can lead to protein misfolding [106] and initiate endoplasmic reticulum (ER) stress $[107,108]$. Therefore, these conditions may contribute to aggregation and toxic deposition of misfolded proteins in the PE placenta and body fluids. At the same time, it is also possible that aggregated proteins deposited in trophoblasts prevent its normal invasion and induce ischemia and ER stress. It has still to be determined whether or not protein aggregation plays a causative role in PE, triggering the defects in trophoblast invasion, endothelial 
cell dysfunction, oxidative stress, etc., or just represents a consequence of these aberrations. However, recent data (reviewed below) clearly point to an amyloid as an emerging biomarker of PE.

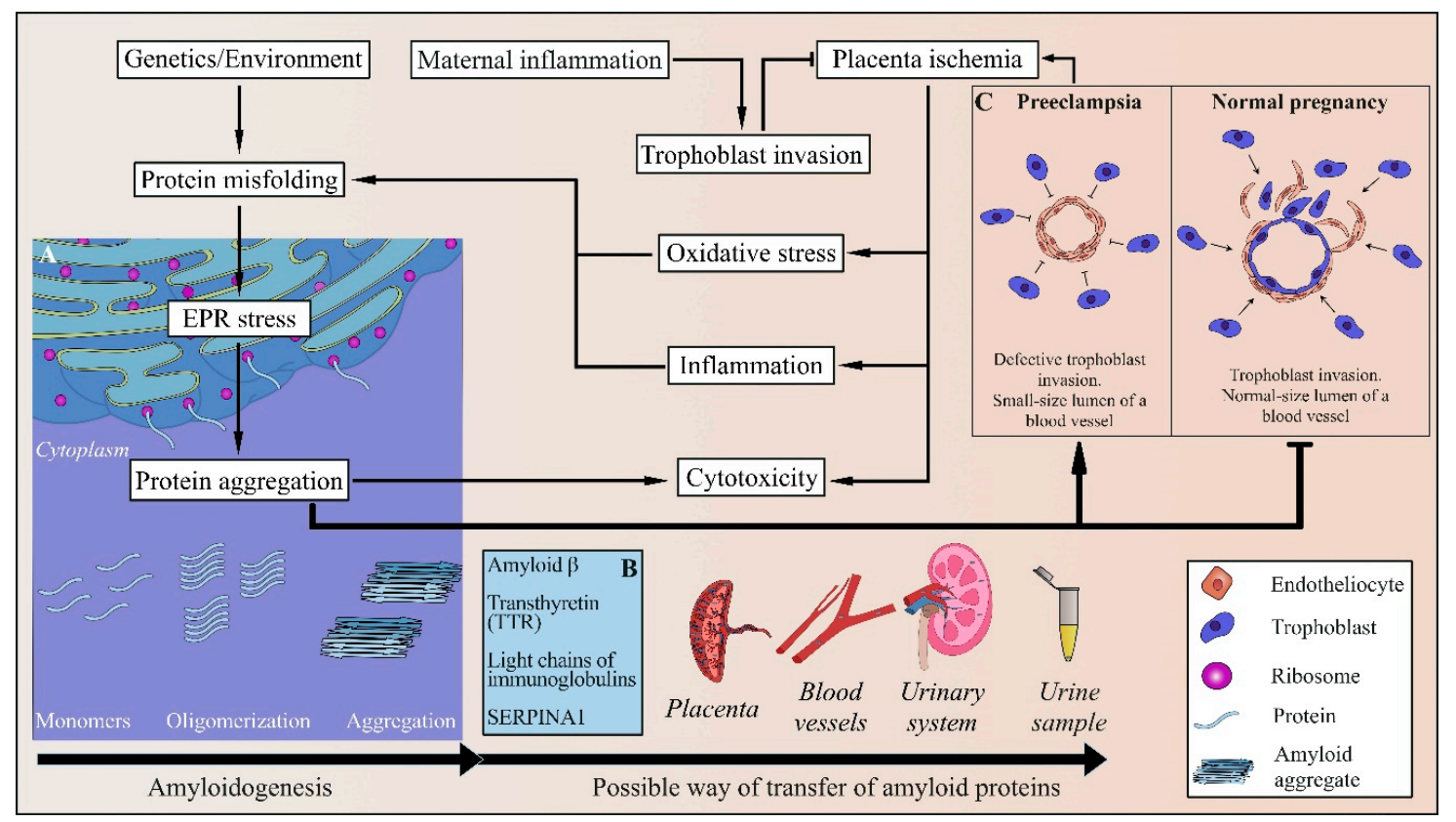

Figure 1. Pathogenesis mechanism of amyloid-based preeclampsia development. In cases of placenta ischemia that is caused by defective trophoblast invasion, oxidative stress, EPR stress, and inflammation may occur. All of these are possible causes of improper protein folding and aggregation. Amyloid aggregation of proteins can cause placenta ischemia. Amyloid aggregates can enter through the placenta into the mother's blood vessels and enter the urinary system through the bloodstream. Amyloid aggregates are found in the urine of women with preeclampsia. (A) During EPR stress, the frequency of protein misfolding increases, which leads to spontaneous aggregation and amyloidogenesis. (B) Proteins capable of amyloid aggregation in preeclampsia include amyloid $\beta$, transthyretin (TTR), immunoglobulin light chains, and alpha-1 antitrypsin. (C) In a normal pregnancy, an invasion of the trophoblasts of the embryo into the spiral arteries of the placenta occurs, which expands the lumen of the vessels and increases the flow of blood to the embryo. During PE, defective trophoblast invasion takes place, which leads to abnormal remodeling of spiral arteries and placenta ischemia.

Since kidney pathology is a hallmark of PE, and proteinuria levels usually correlate with the severity of the disease, Buhimschi et al. [99] performed the proteomic profiling of urine by using mass spectrometry and immunodetection in order to identify biomarkers that would reveal differences between PE patients, healthy women, and, most importantly, patients with proteinuria, which is not related to PE [99]. They found that women with PE (at 34-37 weeks of gestation) display a unique protein profile in their urine that can be used to predict severe PE with high accuracy and makes it possible to distinguish $\mathrm{PE}$ from other disorders associated with hypertension and proteinuria during pregnancy [99,101].

By using A11 and polyclonal aAPF antibodies, specifically binding to amyloid-associated epitopes $[109,110]$, the presence of amyloid-type protofibrils and prefibrillar oligomers in the urine samples from women with PE has been detected [101]. These data were confirmed by the detection of fibrillar arborescent conformations tangled together in larger electrodense structures in the PE urine samples using transmission electron microscopy [101]. These structures were similar to images of fibrils extracted from amyloid-laden tissues [111], although the diameter of PE-associated fibrils was somewhat larger. No fibrils were detected in healthy women and patients with chronic hypertension [101].

By using tandem mass spectrometry (MS) and de novo MS-based protein sequencing, the authors identified some isoforms of alpha-1 antitrypsin and albumin as biomarkers in the urine of PE patients [99], 
that were not present in the urine of non-pregnant women with proteinuria [99]. In addition, the protein component of the urine of pregnant women with $\mathrm{PE}$ also contained $\mathrm{k}$-free light chains of immunoglobulins (IgG), ceruloplasmin, interferon-inducible protein 6-16 (IFI6), and amyloid $\beta$ [101]. Although it is still unclear which specific protein/s is/are present in the fibrillary form in the PE urine samples, all the above-mentioned proteins, with the exception of IF16, were previously reported to undergo pathologic amyloid or amyloid-like aggregation, and are associated with some known human protein misfolding disorders $[112,113]$. Therefore, aggregated proteins could be used as a biomarker for predicting the onset of PE.

\subsection{Alpha-1 Antitrypsin in PE}

For example, increased levels of alpha-1 antitrypsin (a serine protease inhibitor, abundantly present in plasma) are detected in patients with diseases associated with an inflammatory component, such as vasculitis, certain infections, etc. Even minor elevation in the levels of serum alpha- 1 antitrypsin is accompanied by arterial hypertension [114]. Alpha-1 antitrypsin is fragmented, misfolded, and shown to aggregate in response to oxidative stress $[113,115]$. Supramolecular aggregates of misfolded alpha-1 antitrypsin, accumulated in hepatocytes and neurons, have recently been identified as factors in the development of serpinopathies, resulting in liver damage and encephalopathy [116]. High frequency of liver pathologies and neurological disorders in PE women agrees with the possibility of alpha-1 antitrypsin misfolding and aggregate accumulation as one of the manifestations of PE [99].

Moreover, in PE, high alpha-1 antitrypsin immunoreactivity was detected not only in urine but also in the serum and placenta, and significant stromal, endothelial, and intravascular deposition of misfolded alpha-1 antitrypsin aggregates has been reported, although the specific pattern of alpha-1 antitrypsin fragmentation present in urine is specific to PE [99].

\subsection{Light Chains of Immunoglobulins in PE}

The aggregation of immunoglobulin light-chains $(\lambda, \kappa)$ involved in the pathogenesis of light chain (AL) amyloidosis and multiple myeloma [117-120]. AL amyloidosis is the most devastating form of systemic amyloidosis [121]. The disease is caused by deposition of amyloid fibrils, constituted by monoclonal immunoglobulin light chains, which are produced by an abnormally proliferative population of plasma cells [117-120].

Observations that AL amyloidosis most commonly affects kidney, and that patients with PE exhibit proteinuria and kidney damage, suggest that misfolding and aggregation of immunoglobulin light-chains can contribute to the PE-associated pathology.

\subsection{Amyloid $\beta$ in PE}

Amyloid precursor protein (APP) is a ubiquitously expressed transmembrane glycosylated protein with three major isoforms (APP770, APP751, and APP695), which are produced in the result of alternative splicing of the APP gene. In the normal metabolic pathway, APP is first cleaved by $\alpha$-secretase to release a soluble $\mathrm{N}$-terminal fragment (sAPPa). Cleaved sAPPa is non-amyloidogenic and functions as a growth factor that promotes cell survival, proliferation, and migration [83,122]. However, in the amyloidogenic pathway, APP is cleaved by $\beta$-secretase and then c-secretase releasing the short amyloid $\beta(\mathrm{A} \beta$ ) peptide, which is the main component of amyloid plaques observed in the brain in Alzheimer's disease [122-124]. Due to its high propensity for oligomerization and self-assembly, A $\beta$ is considered as a major factor triggering Alzheimer's disease [124-126].

MS analysis has not detected $A \beta$ in the PE urine samples. However, aggregated $A \beta$ could be difficult to detect by MS due to protection from proteolysis, needed for fragmentation that precedes MS analysis. Indeed, APP fragments (including A $\beta$ ) were found in the urine of pregnant women with PE by Western blotting [101] with specific ALZ90 monoclonal antibodies [127,128], possible dysregulation of the proteolytic cleavage of APP during PE. This agrees with increased production of $\alpha$ - (ADAM10) and $\beta$ - (BACE2) in the placenta of women with PE [101]. Expression of one of the $\gamma$-secretase genes 
(PSEN1) and of another gene for $\beta$-secretase (BACE1) was not reported as elevated at the mRNA level in the same tissues, but an increase in the products of these genes in PE trophoblasts has been demonstrated by immunohistochemistry [101]. This discrepancy between approaches is not surprising, as BACE1 expression control includes alternative splicing, post-translational modifications, cellular trafficking, and regulation of degradation [129].

Aside from its presence in the urine, $A \beta$ is accumulated in the placenta of PE women [101]. Previous observations suggested that the placenta expresses APP during normal pregnancy; however, its cleavage and aggregation appear to be increased in the case of PE [104]. It was demonstrated that severe PE is associated with the deposition of amyloid-like aggregates, stained by ALZ90 antibodies [127,128] in the basal plate and villous areas of the placenta [101].

\subsection{Transthyretin in PE}

Recent studies have reported that transthyretin (TTR), a transporter of thyroxine and retinol, which is a known amyloidogenic protein playing a major role in the pathogenesis of familial amyloid polyneuropathy and others TTR-related amyloidosis [130], undergoes dysregulation, misfolding, and aggregation in PE [131]. TTR aggregation may lead to inflammation, oxidative stress, ER stress, and defective deep placentation $[131,132]$. By using specific ProteoStat dye, specifically binding to aggregated proteins, in combination with ELISA, TTR aggregates were found in the placenta and sera from patients with severe PE [131].

This remains unclear which amyloid protein is primarily responsible for the amyloid aggregation detected in PE urine, and whether or not amyloid formation triggers PE. It is possible that amyloidogenic proteins could induce aggregation of each other, so that several proteins could be present in the amyloid form at the advanced stage of the disease.

\subsection{Possible Role of the Human Pregnancy Zone Protein}

Some secreted proteins, known as extracellular chaperones, such as caseins [133], clusterin [134,135], haptoglobin [136], and alpha-2-macroglobulin $(\alpha 2 \mathrm{M})[136,137]$, are implicated as inhibitors of protein misfolding and aggregation [133]. Pregnancy zone protein (PZP), which is very similar to $\alpha 2 \mathrm{M}$, was shown to be significantly elevated in maternal plasma during pregnancy [138]. This can be revealed in serum after 3-4 weeks of gestation $[139,140]$. It was proposed that the high levels of PZP during pregnancy represent a maternal adaptation counteracting protein aggregation, for example via the formation of stable complexes between PZP and A $\beta$. PLZ, which is normally present as a dimer in biological fluids, is known to inhibit heat-induced protein aggregation [103] and could be a candidate for the efficient anti-aggregation chaperone similar to dimeric $\alpha 2 \mathrm{M}$.

Hence, low level of production or dysregulation in the PZP chaperone function resulting in accumulation of misfolded proteins during pregnancy can lead to PE manifestation.

\section{New Approaches to PE Diagnostics}

Over the past twenty years, there has been significant progress in the understanding of pathophysiological mechanisms of $\mathrm{PE}$ and in the identification of new potential biomarkers that can be used in the diagnosis of this pregnancy complication. Some efficient approaches, such as serum sFLt1/PIGF ratio [11,141] or sEng measurement in plasma [142], have been introduced. A competing risks model, a Bayes' theorem based method, which provides an effective approach for the first-trimester prediction of preterm-PE based on maternal characteristics and medical history, biophysical (mean arterial pressure, uterine artery pulsatility index), and biochemical (placental growth factor, soluble fms-like tyrosine kinase-1) markers have been developed $[9,19,143]$. However, there is still a need for the cheap and specific express approach distinguishing PE and other conditions associated with hypertension and proteinuria.

One such approach could be based on MS-based identification of a unique urine proteomic fingerprint predicting PE. Such a protein profile includes alpha-1 antitrypsin, albumin, IgG k-free light 
chains, ceruloplasmin, and interferon-inducible protein 6-16 [99], later these data were supplemented by a-1-antitrypsin, complement 3, haptoglobin, and trypstatin [144]. This could be complemented by detection of increased TTR levels in body fluids [71]. A disadvantage of this approach is that MS-based technology is expensive and requires a lot of time and specific equipment not readily available everywhere.

Another set of approaches employs amyloid-binding dyes, such as thioflavin T [72-74] and Congo red $[89,90]$. It was proposed that aggregates of misfolded protein, which are observed in urine, also circulate in the bloodstream and can be detected by using ThT-enhanced fluorescence. However, it was shown that ThT fluorescence in urine and serum was increased only in severe PE but not in mild forms of PE [100]. Another disadvantage of this method is although there were no gestation age-related changes in ThT fluorescence, enhanced ThT fluorescence was shown for late-stage severe PE (29-35 weeks) [100] when the clinical manifestation of PE has already occurred.

Buhimschi et al. designed a simpler method based on the fact that women with PE demonstrate urine congophilia-an affinity for the amyloidophilic dye CR [101]. CR staining, followed by birefringence in the polarized light, is the gold standard for the demonstration of amyloids in tissue sections [145] and in vitro (Figure 2). Although the mechanism of CR binding to amyloid fibrils is not fully understood, it is known that this phenomenon is reliant on the affinity of $\mathrm{CR}$ for proteins, enriched in $\beta$-sheets [90]. Only amyloids (but not any other CR binding compounds) exhibit a phenomenon of birefringence when bound to $C R$.

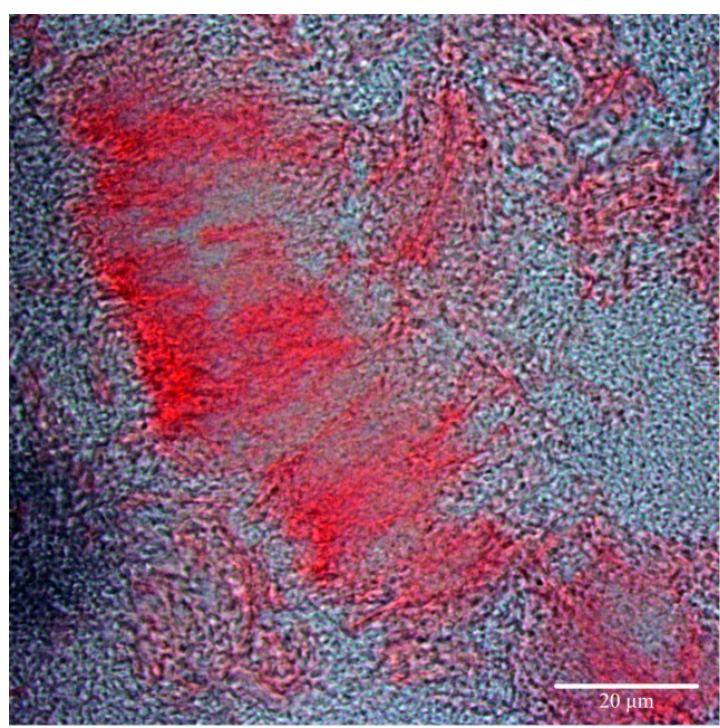

(a)

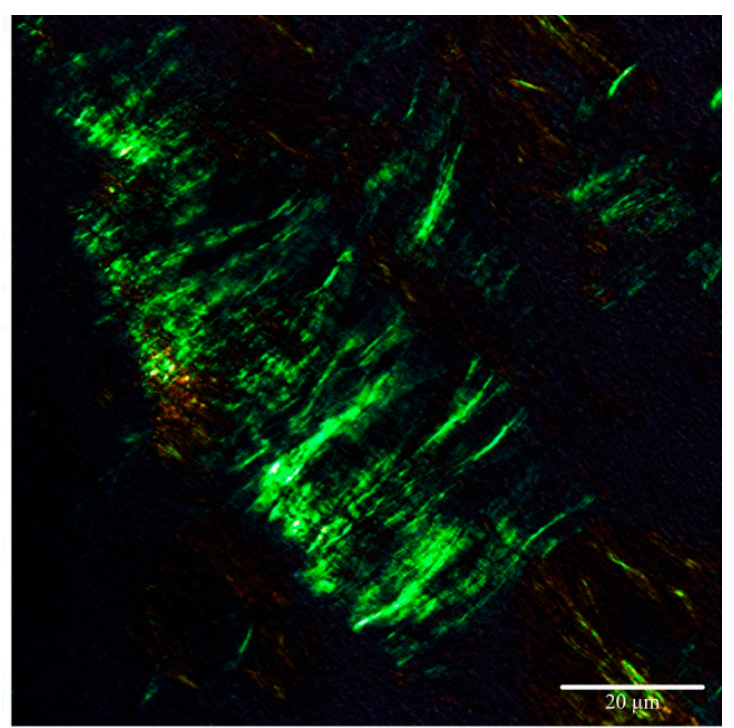

(b)

Figure 2. Congo red-stained amyloid aggregates of recombinant S. cerevisiae Sup35NM protein. (a) Amyloid aggregates of the yeast Sup35NM protein bind to CR; (b) CR-stained Sup35NM aggregates demonstrated yellow to apple-green birefringence under polarized light. Data are obtained by D.V. Kachkin.

Urinary congophilia (that is, the presence of urea components capable of binding CR) has previously been reported for such a "classic" human prion disease as Creutzfeldt-Jakob disease [146]. Buhimschi et al. have shown that the same approach detects amyloids by CR binding in the urine of women with severe PE. In the case of PE, congophilia develops at an early stage of the asymptomatic phase of PE (more than 10 weeks before clinical manifestation of PE) and progressively develops during pregnancy [101]. The detection approach is employing the absorption of urine proteins on the nitrocellulose filter, followed by staining with $\mathrm{CR}$ and washing with methanol (Figure 3). The value of the $C R$ retention after the methanol wash (relative to the value before the wash) was proposed as a 
diagnostic indicator [101]. Moreover, qualitative (visual) detection based on the presence of the red spots on the filter is also doable.

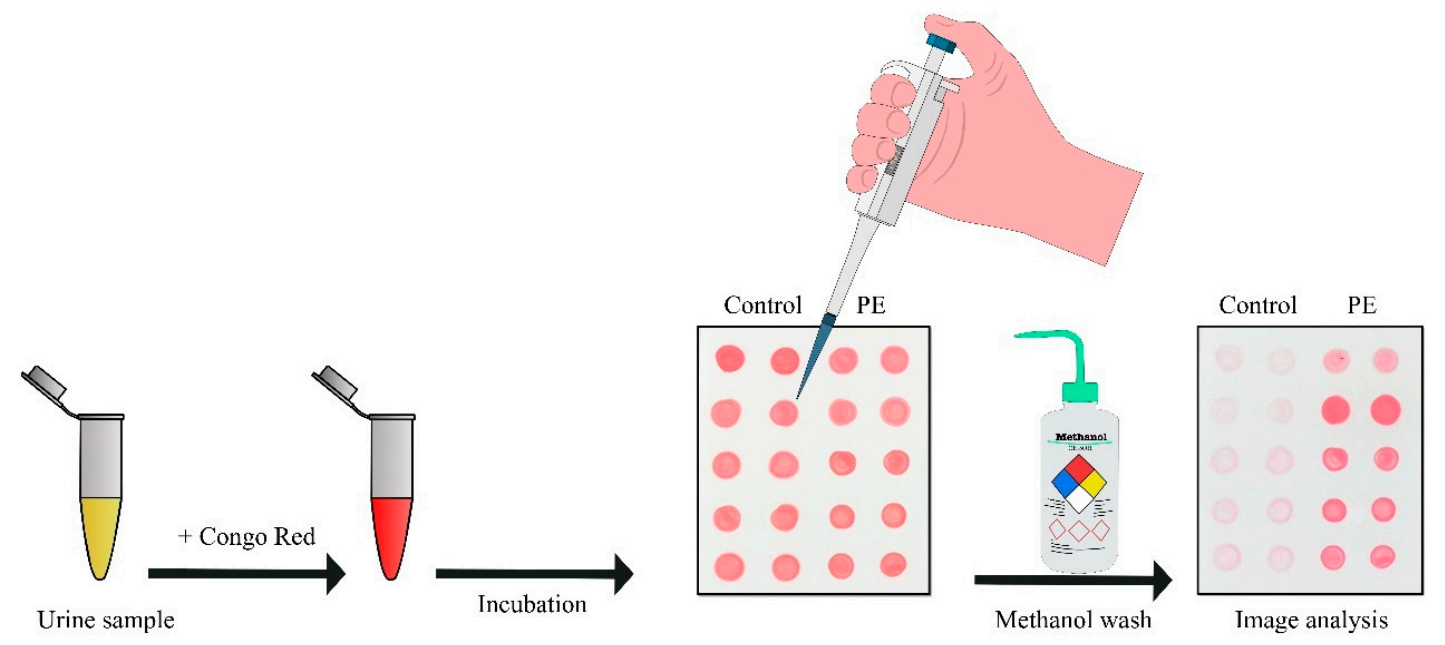

Figure 3. The scheme of the CR dot test for rapid identification of preeclampsia. Urine was mixed with a solution of CR and spotted on a strip of nitrocellulose, which was photographed before and after washing with increasing concentration of methanol. The spots corresponding to PE urine retained the red color, whereas spots of control washed away.

Later, Rood et al. suggested the Congo Red Dot (CRD) paper test as a simple, univocal, non-invasive clinical tool for rapid PE identification [147]. This modification of the detection approach is based on the fact that $\mathrm{CR}$ solution spotted on paper forms hydrogen bonds with cellulose and made a tight circle. However, if in this solution (urine mixed with CR) there are aggregated proteins, they bind to CR and prevent its cellulose binding. Hence, the CR-urine solution spread on the paper forming a wide pink circle. The CRD paper test takes only about 5 minutes and demonstrates high accuracy in PE diagnosis. The authors report that the CRD paper test result can turn positive within 14 days before the clinical manifestation of PE [147]. However, the gestational age of women who took part in the research was generally between 28 and 38 weeks. Usually common PE symptoms can be detected at this stage of pregnancy [20].

Therefore, as of now, diagnostic methods based on protein misfolding during PE are proven to work in the second half of pregnancy, only a few weeks before the PE clinical manifestations. This remains to be determined if these methods are applicable to earlier stages of PE. In the case of amyloid formation playing an important role in disease development, such an applicability is likely, but requires further investigation.

Author Contributions: Conceptualization, E.M.G., Y.O.C., and A.A.R.; validation, S.A.F., A.S.G., Y.O.C., and A.A.R.; writing—original draft preparation, E.M.G.; writing—review and editing, E.M.G., S.A.F., E.S.V., A.S.G., Y.O.C., D.V.K., A.A.R.; Visualization D.V.K.; supervision, Y.O.C. and A.A.R.; project administration, A.S.G., Y.O.C., and A.A.R.; funding acquisition, A.S.G. and Y.O.C.

Funding: This study was financially supported in parts by grant 19-75-20033 from Russian Science Foundation (A.S.G., E.M.G., and E.S.V.), grant 19-34-90153 from Russian Foundation of Basic Research (Y.O.C. and D.V.K.), and by grant from St. Petersburg State University (Y.O.C., E.M.G., and A.A.R.). S.A.F. was supported by Postdoctoral Fellowship program from St. Petersburg State University.

Acknowledgments: The authors are grateful to Konstantin Yu. Kulichikhin (Laboratory of Amyloid Biology, St. Petersburg State University, Russia) for the helpful discussion. We also thank Julia V. Sopova (Laboratory of Amyloid Biology, St. Petersburg State University, Russia) for the assistance with CR staining.

Conflicts of Interest: The authors declare no conflict of interest. 


\section{Abbreviations}

$\begin{array}{ll}\text { PE } & \text { Preeclampsia } \\ \text { CR } & \text { Congo Red } \\ \text { CRD } & \text { Congo Red } \\ \text { BP } & \text { Blood Pressure } \\ \text { sFlt-1 } & \text { Soluble Fms-like tyrosine kinase-1 } \\ \text { sEng } & \text { soluble Endoglin } \\ \text { PLGF } & \text { Placental Growth Factor } \\ \text { sVEGFR } & \text { Vascular Endothelial Growth Factor } \\ \text { VEGF } & \text { Vascular Endothelial Growth Factor } \\ \text { ROS } & \text { Reactive Oxygen Species } \\ \text { HO } & \text { Heme Oxygenase } \\ \text { mRNA } & \text { messenger Ribonucleic Acid } \\ \text { NkB } & \text { Neurokinin B } \\ \text { AT1-AA } & \text { Autoantibodies to Angiotensin II receptor 1 } \\ \text { Apo E } & \text { Apolipoprotein E } \\ \text { TSEs } & \text { Transmissible Spongiform Encephalopathies } \\ \text { A } \beta & \text { Amyloid } \beta \text { peptide } \\ \text { EM } & \text { Electron Microscopy } \\ \text { ER } & \text { Endoplasmic Reticulum } \\ \text { TTR } & \text { Transthyretin } \\ \text { MS } & \text { Mass Spectrometry } \\ \text { igG } & \text { immunoglobulins } \\ \text { IFI-6 } & \text { Interferon-inducible protein 6-16 } \\ \text { APP } & \text { Amyloid Precursor Protein } \\ \text { sAPPa } & \text { soluble N-terminal fragment of APP } \\ \alpha 2 M & \text { alpha-2-macroglobulin } \\ \text { PZP } & \text { Pregnancy Zone Protein } \\ \text { ThT } & \text { Thioflavin-T } \\ & \end{array}$

\section{References}

1. Duley, L. The Global Impact of Pre-eclampsia and Eclampsia. Semin. Perinatol. 2009, 33, 130-137. [CrossRef] [PubMed]

2. American College of Obstetricians; Task Force on Hypertension in Pregnancy. Hypertension in pregnancy. Report of the American College of Obstetricians and Gynecologists' Task Force on Hypertension in Pregnancy. Obstet. Gynecol. 2013, 122, 1122-1131. [CrossRef]

3. Tranquilli, A.L.; Dekker, G.; Magee, L.; Roberts, J.; Sibai, B.M.; Steyn, W.; Zeeman, G.G.; Brown, M.A. The classification, diagnosis and management of the hypertensive disorders of pregnancy: A revised statement from the ISSHP. Pregnancy Hypertens. Int. J. Women's Cardiovasc. Health 2014, 4, 97-104. [CrossRef] [PubMed]

4. Brown, M.A.; Magee, L.A.; Kenny, L.C.; Karumanchi, S.A.; McCarthy, F.P.; Saito, S.; Hall, D.R.; Warren, C.E.; Adoyi, G.; Ishaku, S. Hypertensive disorders of pregnancy: ISSHP classification, diagnosis, and management recommendations for international practice. Hypertension 2018, 72, 24-43. [CrossRef] [PubMed]

5. Sircar, M.; Thadhani, R.; Karumanchi, S.A. Pathogenesis of preeclampsia. Curr. Opin. Nephrol. Hypertens. 2015, 24, 131-138. [CrossRef] [PubMed]

6. Ghulmiyyah, L.; Sibai, B. Maternal Mortality from Preeclampsia/Eclampsia. Semin. Perinatol. 2012, 36, 56-59. [CrossRef] [PubMed]

7. Hod, T.; Cerdeira, A.S.; Karumanchi, S.A. Molecular Mechanisms of Preeclampsia. Cold Spring Harb. Perspect. Med. 2015, 5, a023473. [CrossRef]

8. Wu, P.; van den Berg, C.; Alfirevic, Z.; O’Brien, S.; Röthlisberger, M.; Baker, P.; Kenny, L.; Kublickiene, K.; Duvekot, J. Early Pregnancy Biomarkers in Pre-Eclampsia: A Systematic Review and Meta-Analysis. Int. J. Mol. Sci. 2015, 16, 23035-23056. [CrossRef] 
9. Wright, D.; Tan, M.Y.; O'Gorman, N.; Poon, L.C.; Syngelaki, A.; Wright, A.; Nicolaides, K.H. Predictive performance of the competing risk model in screening for preeclampsia. Am. J. Obstet. Gynecol. 2019, 220, e1-e199. [CrossRef]

10. Schiettecatte, J.; Russcher, H.; Anckaert, E.; Mees, M.; Leeser, B.; Tirelli, A.S.; Fiedler, G.M.; Luthe, H.; Denk, B.; Smitz, J. Multicenter evaluation of the first automated Elecsys sFlt-1 and PIGF assays in normal pregnancies and preeclampsia. Clin. Biochem. 2010, 43, 768-770. [CrossRef]

11. Salahuddin, S.; Lee, Y.; Vadnais, M.; Sachs, B.P.; Karumanchi, S.A.; Lim, K.-H. Diagnostic utility of soluble fms-like tyrosine kinase 1 and soluble endoglin in hypertensive diseases of pregnancy. Am. J. Obstet. Gynecol. 2007, 197, e1-e28. [CrossRef] [PubMed]

12. Levine, R.J.; Maynard, S.E.; Qian, C.; Lim, K.-H.; England, L.J.; Yu, K.F.; Schisterman, E.F.; Thadhani, R.; Sachs, B.P.; Epstein, F.H.; et al. Circulating angiogenic factors and the risk of preeclampsia. N. Engl. J. Med. 2004, 350, 672-683. [CrossRef] [PubMed]

13. Sovio, U.; Gaccioli, F.; Cook, E.; Hund, M.; Charnock-Jones, D.S.; Smith, G.C.S. Prediction of Preeclampsia Using the Soluble fms-Like Tyrosine Kinase 1 to Placental Growth Factor Ratio: A Prospective Cohort Study of Unselected Nulliparous Women. Hypertension 2017, 69, 731-738. [CrossRef] [PubMed]

14. Wortelboer, E.; Koster, M.; Cuckle, H.; Stoutenbeek, P.; Schielen, P.; Visser, G. First-trimester placental protein 13 and placental growth factor: Markers for identification of women destined to develop early-onset pre-eclampsia. Int. J. Obstet. Gynaecol. 2010, 117, 1384-1389. [CrossRef]

15. Nicolaides, K.H.; Bindra, R.; Turan, O.M.; Chefetz, I.; Sammar, M.; Meiri, H.; Tal, J.; Cuckle, H.S. A novel approach to first-trimester screening for early pre-eclampsia combining serum PP-13 and Doppler ultrasound. Ultrasound Obstet. Gynecol. 2005, 27, 13-17. [CrossRef]

16. Venkatesha, S.; Toporsian, M.; Lam, C.; Hanai, J.; Mammoto, T.; Kim, Y.M.; Bdolah, Y.; Lim, K.-H.; Yuan, H.-T.; Libermann, T.A.; et al. Soluble endoglin contributes to the pathogenesis of preeclampsia. Nat. Med. 2006, 12, 642-649. [CrossRef]

17. Foidart, J.-M.; Munaut, C.; Chantraine, F.; Akolekar, R.; Nicolaides, K.H. Maternal plasma soluble endoglin at 11-13 weeks' gestation in pre-eclampsia. Ultrasound Obstet. Gynecol. 2010, 35, 680-687. [CrossRef]

18. Spencer, K.; Cowans, N.J.; Nicolaides, K.H. Low levels of maternal serum PAPP-A in the first trimester and the risk of pre-eclampsia. Prenat. Diagn. 2008, 28, 7-10. [CrossRef]

19. Poon, L.C.; Nicolaides, K.H. Early Prediction of Preeclampsia. Obstet. Gynecol. Int. 2014, $2014,1-11$. [CrossRef]

20. Diagnosis and management of preeclampsia and eclampsia. Int. J. Gynecol. Obstet. 2002, 77, 67-75. [CrossRef]

21. Lowe, S.A.; Brown, M.A.; Dekker, G.A.; Gatt, S.; McLintock, C.K.; McMahon, L.P.; Mangos, G.; Moore, M.P.; Muller, P.; Paech, M.; et al. Guidelines for the management of hypertensive disorders of pregnancy 2008. Aust. N. Z. J. Obstet. Gynaecol. 2009, 49, 242-246. [CrossRef] [PubMed]

22. Morgan, M.A.; Thurnau, G.R. Pregnancy-induced hypertension without proteinuria: Is it true preeclampsia? South. Med. J. 1988, 81, 210-213. [CrossRef] [PubMed]

23. Meyer, N.L.; Mercer, B.M.; Friedman, S.A.; Sibai, B.M. Urinary dipstick protein: A poor predictor of absent or severe proteinuria. Am. J. Obstet. Gynecol. 1994, 170, 137-141. [CrossRef]

24. Lindheimer, M.D.; Kanter, D. Interpreting abnormal proteinuria in pregnancy: The need for a more pathophysiological approach. Obstet. Gynecol. 2010, 115, 365-375. [CrossRef] [PubMed]

25. Brown, M.A.; Buddle, M.L. Inadequacy of dipstick proteinuria in hypertensive pregnancy. Aust. N. Z. J. Obstet. Gynaecol. 1995, 35, 366-369. [CrossRef] [PubMed]

26. Grauer, G.F. Proteinuria: Measurement and interpretation. Top. Companion Anim. Med. 2011, 26, $121-127$. [CrossRef]

27. Shamshirsaz, A.A.; Paidas, M.; Krikun, G. Preeclampsia, Hypoxia, Thrombosis, and Inflammation. J. Pregnancy 2012, 2012, 1-6. [CrossRef]

28. Roberts, J.M.; Gammill, H.S. Preeclampsia: Recent insights. Hypertension 2005, 46, 1243-1249. [CrossRef]

29. Von Dadelszen, P.; Magee, L.A.; Roberts, J.M. Subclassification of Preeclampsia. Hypertens. Pregnancy 2003, 22, 143-148. [CrossRef]

30. Ødegård, R.A.; Vatten, L.J.; Nilsen, S.T.; Salvesen, K.; Austgulen, R. Risk factors and clinical manifestations of pre-eclampsia. Br. J. Obstet. Gynaecol. 2000, 107, 1410-1416. [CrossRef] 
31. Masuyama, H.; Segawa, T.; Sumida, Y.; Masumoto, A.; Inoue, S.; Akahori, Y.; Hiramatsu, Y. Different profiles of circulating angiogenic factors and adipocytokines between early- and late-onset pre-eclampsia. Int. J. Obstet. Gynaecol. 2010, 117, 314-320. [CrossRef] [PubMed]

32. Phipps, E.; Prasanna, D.; Brima, W.; Jim, B. Preeclampsia: Updates in pathogenesis, definitions, and guidelines. Clin. J. Am. Soc. Nephrol. 2016, 11, 1102-1113. [CrossRef] [PubMed]

33. Sibai, B.M. Evaluation and management of severe preeclampsia before 34 weeks' gestation. Am. J. Obstet. Gynecol. 2011, 205, 191-198. [CrossRef] [PubMed]

34. Leavey, K.; Bainbridge, S.A. Cox Large scale aggregate microarray analysis reveals three distinct molecular subclasses of human preeclampsia. PLoS ONE 2015, 10, e0116508. [CrossRef]

35. Leavey, K.; Benton, S.J.; Grynspan, D.; Kingdom, J.C.; Bainbridge, S.A.; Cox, B.J. Unsupervised Placental Gene Expression Profiling Identifies Clinically Relevant Subclasses of Human Preeclampsia. Hypertension 2016, 68, 137-147. [CrossRef]

36. Chaiworapongsa, T.; Chaemsaithong, P.; Yeo, L.; Romero, R. Pre-eclampsia part 1: Current understanding of its pathophysiology. Nat. Rev. Nephrol. 2014, 10, 466-480. [CrossRef]

37. Gilbert, J.S.; Babcock, S.A.; Granger, J.P. Hypertension Produced by Reduced Uterine Perfusion in Pregnant Rats Is Associated With Increased Soluble Fms-Like Tyrosine Kinase-1 Expression. Hypertension 2007, 50, 1142-1147. [CrossRef]

38. Kaufmann, P.; Black, S.; Huppertz, B. Endovascular Trophoblast Invasion: Implications for the Pathogenesis of Intrauterine Growth Retardation and Preeclampsia. Biol. Reprod. 2003, 69, 1-7. [CrossRef]

39. Brosens, I.; Renaer, M. On the pathogenesis of placental infarcts in pre-eclampsia. Int. J. Obstet. Gynaecol. 1972, 79, 794-799. [CrossRef]

40. Levine, R.J.; Lam, C.; Qian, C.; Yu, K.F.; Maynard, S.E.; Sachs, B.P.; Sibai, B.M.; Epstein, F.H.; Romero, R.; Thadhani, R.; et al. Soluble Endoglin and Other Circulating Antiangiogenic Factors in Preeclampsia. N. Engl. J. Med. 2006, 355, 992-1005. [CrossRef]

41. Harihana, N.; Shoemaker, A.; Wagner, S. Pathophysiology of hypertension in preeclampsia. Clin. Pr. 2016, 13, 33-37.

42. Than, N.G.; Romero, R.; Tarca, A.L.; Kekesi, K.A.; Xu, Y.; Xu, Z.; Juhasz, K.; Bhatti, G.; Leavitt, R.J.; Gelencser, Z.; et al. Integrated Systems Biology Approach Identifies Novel Maternal and Placental Pathways of Preeclampsia. Front. Immunol. 2018, 9, 1661. [CrossRef]

43. El-Sayed, A.A.F. Preeclampsia: A review of the pathogenesis and possible management strategies based on its pathophysiological derangements. Taiwan. J. Obstet. Gynecol. 2017, 56, 593-598. [CrossRef] [PubMed]

44. Maynard, S.E.; Min, J.-Y.; Merchan, J.; Lim, K.-H.; Li, J.; Mondal, S.; Libermann, T.A.; Morgan, J.P.; Sellke, F.W.; Stillman, I.E.; et al. Excess placental soluble fms-like tyrosine kinase 1 (sFlt1) may contribute to endothelial dysfunction, hypertension, and proteinuria in preeclampsia. J. Clin. Investig. 2003, 111, 649-658. [CrossRef] [PubMed]

45. Ohkuchi, A.; Hirashima, C.; Suzuki, H.; Takahashi, K.; Yoshida, M.; Matsubara, S.; Suzuki, M. Evaluation of a new and automated electrochemiluminescence immunoassay for plasma sFlt-1 and PlGF levels in women with preeclampsia. Hypertens. Res. 2010, 33, 422-427. [CrossRef]

46. Knudsen, U.B.; Kronborg, C.S.; von Dadelszen, P.; Kupfer, K.; Lee, S.-W.; Vittinghus, E.; Allen, J.G.; Redman, C.W. A single rapid point-of-care placental growth factor determination as an aid in the diagnosis of preeclampsia. Pregnancy Hypertens. Int. J. Women's Cardiovasc. Health 2012, 2, 8-15. [CrossRef]

47. Burton, G.J.; Jauniaux, E. Oxidative stress. Best Pract. Res. Clin. Obstet. Gynaecol. 2011, 25, 287-299. [CrossRef]

48. Myatt, L.; Cui, X. Oxidative stress in the placenta. Histochem. Cell Biol. 2004, 122, 369-382. [CrossRef]

49. Cindrova-Davies, T.; Spasic-Boskovic, O.; Jauniaux, E.; Charnock-Jones, D.S.; Burton, G.J. Nuclear Factor- $k$ B, p38, and Stress-Activated Protein Kinase Mitogen-Activated Protein Kinase Signaling Pathways Regulate Proinflammatory Cytokines and Apoptosis in Human Placental Explants in Response to Oxidative Stress. Am. J. Pathol. 2007, 170, 1511-1520. [CrossRef]

50. Zenclussen, A.C.; Lim, E.; Knoeller, S.; Knackstedt, M.; Hertwig, K.; Hagen, E.; Klapp, B.F.; Arck, P.C. Heme Oxygenases in Pregnancy II: HO-2 is Downregulated in Human Pathologic Pregnancies. Am. J. Reprod. Immunol. 2003, 50, 66-76. [CrossRef]

51. Lyall, F.; Barber, A.; Myatt, L.; Bulmer, J.N.; Robson, S.C. Hemeoxygenase expression in human placenta and placental bed implies a role in regulation of trophoblast invasion and placental function. FASEB J. 2000, 14, 208-219. [CrossRef] [PubMed] 
52. George, E.M.; Granger, J.P. Heme oxygenase in pregnancy and preeclampsia. Curr. Opin. Nephrol. Hypertens. 2013, 22, 156-162. [CrossRef] [PubMed]

53. Bainbridge, S.; Farley, A.; McLaughlin, B.; Graham, C.; Marks, G.; Nakatsu, K.; Brien, J.; Smith, G. Carbon Monoxide Decreases Perfusion Pressure in Isolated Human Placenta. Placenta 2002, 23, 563-569. [CrossRef] [PubMed]

54. Cudmore, M.; Ahmad, S.; Al-Ani, B.; Fujisawa, T.; Coxall, H.; Chudasama, K.; Devey, L.R.; Wigmore, S.J.; Abbas, A.; Hewett, P.W.; et al. Negative Regulation of Soluble Flt-1 and Soluble Endoglin Release by Heme Oxygenase-1. Circulation 2007, 115, 1789-1797. [CrossRef] [PubMed]

55. McCaig, D.; Lyall, F. Inhibitors of Heme Oxygenase Reduce Invasion of Human Primary Cytotrophoblast Cells In vitro. Placenta 2009, 30, 536-538. [CrossRef]

56. Costantine, M.M.; Tamayo, E.; Lu, F.; Bytautiene, E.; Longo, M.; Hankins, G.D.V.; Saade, G.R. Using Pravastatin to Improve the Vascular Reactivity in a Mouse Model of Soluble Fms-Like Tyrosine Kinase-1-Induced Preeclampsia. Obstet. Gynecol. 2010, 116, 114-120. [CrossRef]

57. Brosens, I.; Pijnenborg, R.; Vercruysse, L.; Romero, R. The "Great Obstetrical Syndromes" are associated with disorders of deep placentation. Am. J. Obstet. Gynecol. 2011, 204, 193-201. [CrossRef]

58. Kim, Y.M.; Bujold, E.; Chaiworapongsa, T.; Gomez, R.; Yoon, B.H.; Thaler, H.T.; Rotmensch, S.; Romero, R. Failure of physiologic transformation of the spiral arteries in patients with preterm labor and intact membranes. Am. J. Obstet. Gynecol. 2003, 189, 1063-1069. [CrossRef]

59. Dommisse, J.; Tiltman, A.J. Placental bed biopsies in placental abruption. Int. J. Obstet. Gynaecol. 1992, 99, 651-654. [CrossRef]

60. Page, N.; Butlin, D.; Manyonda, I.; Lowry, P. The development of a genetic profile of placental gene expression during the first trimester of pregnancy: A potential tool for identifying novel secreted markers. Fetal Diagn. Ther. 2000, 15, 237-245. [CrossRef]

61. Zulfikaroglu, E.; Ugur, M.; Taflan, S.; Ugurlu, N.; Atalay, A.; Kalyoncu, S. Neurokinin B levels in maternal and umbilical cord blood in preeclamptic and normal pregnancies. J. Perinat. Med. 2007, 35, 200-202. [CrossRef] [PubMed]

62. Page, N.M.; Kemp, C.F.; Butlin, D.J.; Lowry, P.J. Placental peptides as markers of gestational disease. Reproduction 2002, 123, 487-495. [CrossRef] [PubMed]

63. Laliberte, C.; DiMarzo, L.; Morrish, D.W.; Kaufman, S. Neurokinin B causes concentration-dependent relaxation of isolated human placental resistance vessels. Regul. Pept. 2004, 117, 123-126. [CrossRef] [PubMed]

64. Pal, S.; Wu, J.; Murray, J.K.; Gellman, S.H.; Wozniak, M.A.; Keely, P.J.; Boyer, M.E.; Gomez, T.M.; Hasso, S.M.; Fallon, J.F.; et al. An antiangiogenic neurokinin-B/thromboxane A2 regulatory axis. J. Cell Biol. 2006, 174, 1047-1058. [CrossRef]

65. Page, N.M. Neurokinin B and pre-eclampsia: A decade of discovery. Reprod. Biol. Endocrinol. $2010,8,4$. [CrossRef]

66. Hoang, V.M.; Foulk, R.; Clauser, K.; Burlingame, A.; Gibson, B.W.; Fisher, S.J. Functional Proteomics: Examining the Effects of Hypoxia on the Cytotrophoblast Protein Repertoire. Biochemistry 2001, 40, 4077-4086. [CrossRef]

67. Sawicki, G.; Dakour, J.; Morrish, D.W. Functional proteomics of neurokinin B in the placenta indicates a novel role in regulating cytotrophoblast antioxidant defences. Proteomics 2003, 3, 2044-2051. [CrossRef]

68. Xie, F.; von Dadelszen, P.; Nadeau, J. CMV infection, TLR-2 and -4 expression, and cytokine profiles in early-onset preeclampsia with HELLP syndrome. Am. J. Reprod. Immunol. 2014, 71, 379-386. [CrossRef]

69. Molvarec, A.; Szarka, A.; Walentin, S.; Bekő, G.; Karádi, I.; Prohászka, Z.; Rigó, J., Jr. Serum leptin levels in relation to circulating cytokines, chemokines, adhesion molecules and angiogenic factors in normal pregnancy and preeclampsia. Reprod. Biol. Endocrinol. 2011, 9, 124. [CrossRef]

70. Wallukat, G.; Homuth, V.; Fischer, T.; Lindschau, C.; Horstkamp, B.; Jüpner, A.; Baur, E.; Nissen, E.; Vetter, K.; Neichel, D.; et al. Patients with preeclampsia develop agonistic autoantibodies against the angiotensin AT1 receptor. J. Clin. Investig. 1999, 103, 945-952. [CrossRef]

71. Chaiworapongsa, T.; Romero, R.; Yoshimatsu, J.; Espinoza, J.; Kim, Y.M.; Park, K.; Kalache, K.; Edwin, S.; Bujold, E.; Gomez, R. Soluble adhesion molecule profile in normal pregnancy and pre-eclampsia. J. Matern. Neonatal Med. 2002, 12, 19-27. [CrossRef] [PubMed] 
72. Bretelle, F.; Sabatier, F.; Blann, A.; D’Ercole, C.; Boutière, B.; Mutin, M.; Boubli, L.; Sampol, J.; Dignat-George, F. Maternal endothelial soluble cell adhesion molecules with isolated small for gestational age fetuses: Comparison with pre-eclampsia. Br. J. Obstet. Gynaecol. 2001, 108, 1277-1282.

73. Francoual, J.; Audibert, F.; Trioche, P.; Chalas, J.; Capel, L.; Lindenbaum, A.; Labrune, P.; Frydman, R. Erratum: Is a Polymorphism of the Apolipoprotein E Gene Associated with Preeclampsia? Hypertens. Pregnancy 2003, 21, 127-133. [CrossRef] [PubMed]

74. Belo, L.; Gaffney, D.; Caslake, M.; Santos-Silva, A.; Pereira-Leite, L.; Quintanilha, A.; Rebelo, I. Apolipoprotein $\mathrm{E}$ and cholesteryl ester transfer protein polymorphisms in normal and preeclamptic pregnancies. Eur. J. Obstet. Gynecol. Reprod. Biol. 2004, 112, 9-15. [CrossRef]

75. Aguzzi, A.; Haass, C. Games played by rogue proteins in prion disorders and Alzheimer's disease. Science 2003, 302, 814-818. [CrossRef]

76. Soto, C. Unfolding the role of protein misfolding in neurodegenerative diseases. Nat. Rev. Neurosci. 2003, 4, 49-60. [CrossRef]

77. Labbadia, J.; Morimoto, R.I. The Biology of Proteostasis in Aging and Disease. Annu. Rev. Biochem. 2015, 84, 435-464. [CrossRef]

78. Wiggins, R.C. Prions and the Transmissible Spongiform Encephalopathies. In Metabolic Encephalopathy; McCandless, D., Ed.; Springer: New York, NY, USA, 2009; pp. 531-550.

79. Belay, E.D. Transmissible Spongiform Encephalopathies in Humans. Annu. Rev. Microbiol. 1999, 53, $283-314$. [CrossRef]

80. Geschwind, M.D.; Legname, G. Transmissible spongiform encephalopathies. In Protein Misfolding in Neurodegenerative Diseases: Mechanisms and Therapeutic Strategies; CRC Press; Smith, H.J., Simons, C., Sewell, R.D.E., Eds.; Taylor and Francis Group: Abingdon, UK, 2007; pp. 221-248.

81. Iwasaki, Y. Creutzfeldt-Jakob disease. Neuropathology. 2017, 2, 174-188. [CrossRef]

82. Brown, K.; Mastrianni, J.A. The Prion Diseases. J. Geriatr. Psychiatry Neurol. 2010, 23, 277-298. [CrossRef]

83. Bhadbhade, A.; Cheng, D.W. Amyloid Precursor Protein Processing in Alzheimer's Disease. Iran. J. Child Neurol. 2012, 34, 185-204.

84. Iqbal, K.; Alonso, A.; Chen, S.; Chohan, M.O.; El-Akkad, E.; Gong, C.-X.; Khatoon, S.; Li, B.; Liu, F.; Rahman, A.; et al. Tau pathology in Alzheimer disease and other tauopathies. Biochim. Biophys. Acta Mol. Basis Dis. 2005, 1739, 198-210. [CrossRef] [PubMed]

85. Iqbal, K.; Liu, F.; Gong, C.-X.; Grundke-Iqbal, I. Tau in Alzheimer Disease and Related Tauopathies. Curr. Alzheimer Res. 2010, 7, 656-664. [CrossRef] [PubMed]

86. Tysnes, O.B.; Storstein, A. Epidemiology of Parkinson's disease. J. Neural Transm. 2017, 124, 901-905. [CrossRef] [PubMed]

87. Yasuda, T.; Nakata, Y.; Mochizuki, H. $\alpha$-Synuclein and neuronal cell death. Mol. Neurobiol. 2013, 47, $466-483$. [CrossRef] [PubMed]

88. Imran, M.; Mahmood, S. An overview of human prion diseases. Virol. J. 2011, 8, 559. [CrossRef]

89. Wu, C.; Wang, Z.; Lei, H.; Zhang, W.; Duan, Y. Dual binding modes of Congo red to amyloid protofibril surface observed in molecular dynamics simulations. J. Am. Chem. Soc. 2007, 129, 1225-1232. [CrossRef]

90. Frid, P.; Anisimov, S.V.; Popovic, N. Congo red and protein aggregation in neurodegenerative diseases. Brain Res. Rev. 2007, 53, 135-160. [CrossRef]

91. Naiki, H.; Higuchi, K.; Hosokawa, M.; Takeda, T. Fluorometric determination of amyloid fibrils in vitro using the fluorescent dye, thioflavine T. Anal. Biochem. 1989, 177, 244-249. [CrossRef]

92. Ivancic, V.A.; Ekanayake, O.; Lazo, N.D. Binding Modes of Thioflavin T on the Surface of Amyloid Fibrils Studied by NMR. ChemPhysChem 2016, 17, 2461-2464. [CrossRef]

93. Levine, $\mathrm{H}$. Thioflavine $\mathrm{t}$ interaction with amyloid $\beta$ sheet structures. Amyloid 1995, 2, 1-6. [CrossRef]

94. Kayed, R.; Head, E.; Sarsoza, F.; Saing, T.; Cotman, C.W.; Necula, M.; Margol, L.; Wu, J.; Breydo, L.; Thompson, J.L.; et al. Fibril specific, conformation dependent antibodies recognize a generic epitope common to amyloid fibrils and fibrillar oligomers that is absent in prefibrillar oligomers. Mol. Neurodegener. 2007, 2, 18. [CrossRef] [PubMed]

95. Gremer, L.; Schölzel, D.; Schenk, C.; Reinartz, E.; Labahn, J.; Ravelli, R.B.G.; Tusche, M.; Lopez-Iglesias, C.; Hoyer, W.; Heise, H.; et al. Fibril structure of amyloid- $\beta$ (1-42) by cryo-electron microscopy. Science 2017, 358, 116-119. [CrossRef] [PubMed] 
96. Sunde, M.; Blake, C. The structure of amyloid fibrils by electron microscopy and x-ray diffraction. Adv. Protein Chem. 1997, 50, 123-159. [PubMed]

97. Chandramowlishwaran, P.; Sun, M.; Casey, K.L.; Romanyuk, A.V.; Grizel, A.V.; Sopova, J.V.; Rubel, A.A.; Nussbaum-Krammer, C.; Vorberg, I.M.; Chernoff, Y.O. Mammalian amyloidogenic proteins promote prion nucleation in yeast. J. Biol. Chem. 2018, 293, 3436-3450. [CrossRef] [PubMed]

98. Rubel, A.A.; Ryzhova, T.A.; Antonets, K.S.; Chernoff, Y.O.; Galkin, A.P. Identification of PrP sequences essential for the interaction between the PrP polymers and A $\beta$ peptide in a yeast-based assay. Prion 2013, 7, 469-476. [CrossRef]

99. Buhimschi, I.A.; Zhao, G.; Funai, E.F.; Harris, N.; Sasson, I.E.; Bernstein, I.M.; Saade, G.R.; Buhimschi, C.S. Proteomic profiling of urine identifies specific fragments of SERPINA1 and albumin as biomarkers of preeclampsia. Am. J. Obstet. Gynecol. 2008, 199, e1-e551. [CrossRef]

100. Millen, K.R.; Buhimschi, C.S.; Zhao, G.; Rood, K.M.; Tabbah, S.; Buhimschi, I.A. Serum and Urine Thioflavin-T-Enhanced Fluorescence in Severe Preeclampsia. Hypertension 2018, 71, 1185-1192. [CrossRef]

101. Buhimschi, I.A.; Nayeri, U.A.; Zhao, G.; Shook, L.L.; Pensalfini, A.; Funai, E.F.; Bernstein, I.M.; Glabe, C.G.; Buhimschi, C.S. Protein misfolding, congophilia, oligomerization, and defective amyloid processing in preeclampsia. Sci. Transl. Med. 2014, 6, 245ra92. [CrossRef]

102. Tong, M.; Cheng, S.; Chen, Q.; DeSousa, J.; Stone, P.R.; James, J.L.; Chamley, L.W.; Sharma, S. Aggregated transthyretin is specifically packaged into placental nano-vesicles in preeclampsia. Sci. Rep. 2017, 7, 6694. [CrossRef]

103. Cater, J.H.; Kumita, J.R.; Zeineddine Abdallah, R.; Zhao, G.; Bernardo-Gancedo, A.; Henry, A.; Winata, W.; Chi, M.; Grenyer, B.S.F.; Townsend, M.L.; et al. Human pregnancy zone protein stabilizes misfolded proteins including preeclampsia- and Alzheimer's-associated amyloid beta peptide. Proc. Natl. Acad. Sci. USA 2019, 116, 6101-6110. [CrossRef] [PubMed]

104. Cheng, S.-B.; Nakashima, A.; Sharma, S. Understanding Pre-Eclampsia Using Alzheimer's Etiology: An Intriguing Viewpoint. Am. J. Reprod. Immunol. 2016, 75, 372-381. [CrossRef] [PubMed]

105. Tartaglia, G.G.; Pechmann, S.; Dobson, C.M.; Vendruscolo, M. Life on the edge: A link between gene expression levels and aggregation rates of human proteins. Trends Biochem. Sci. 2007, 32, 204-206. [CrossRef] [PubMed]

106. Mao, X.R.; Crowder, C.M. Protein Misfolding Induces Hypoxic Preconditioning via a Subset of the Unfolded Protein Response Machinery. Mol. Cell. Biol. 2010, 30, 5033-5042. [CrossRef] [PubMed]

107. Paschen, W.; Mengesdorf, T. Endoplasmic reticulum stress response and neurodegeneration. Cell Calcium 2005, 38, 409-415. [CrossRef] [PubMed]

108. Jian, B.; Hsieh, C.H.; Chen, J.; Choudhry, M.; Bland, K.; Chaudry, I.; Raju, R. Activation of endoplasmic reticulum stress response following trauma-hemorrhage. Biochim. Biophys. Acta Mol. Basis Dis. 2008, 1782, 621-626. [CrossRef]

109. Kayed, R.; Head, E.; Thompson, J.L.; McIntire, T.M.; Milton, S.C.; Cotman, C.W.; Glabe, C.G. Common structure of soluble amyloid oligomers implies common mechanism of pathogenesis. Science 2003, 300, 486-489. [CrossRef]

110. Yoshiike, Y.; Kayed, R.; Milton, S.C.; Takashima, A.; Glabe, C.G. Pore-forming proteins share structural and functional homology with amyloid oligomers. Neuromol. Med. 2007, 9, 270-275. [CrossRef]

111. Shirahama, T. High-resolution electron microscopic analysis of the amyloid fibril. J. Cell Biol. 1967, 33, 679-708. [CrossRef]

112. Kumar, S.; Dispenzieri, A.; Katzmann, J.A.; Larson, D.R.; Colby, C.L.; Lacy, M.Q.; Hayman, S.R.; Buadi, F.K.; Leung, N.; Zeldenrust, S.R.; et al. Serum immunoglobulin free light-chain measurement in primary amyloidosis: Prognostic value and correlations with clinical features. Blood 2010, 116, 5126-5129. [CrossRef]

113. Huntington, J.A. Serpin structure, function and dysfunction. J. Thromb. Haemost. 2011, 9, 26-34. [CrossRef] [PubMed]

114. Engström, G.; Janzon, L.; Berglund, G.; Lind, P.; Stavenow, L.; Hedblad, B.; Lindgärde, F. Blood Pressure Increase and Incidence of Hypertension in Relation to Inflammation-Sensitive Plasma Proteins. Arterioscler. Thromb. Vasc. Biol. 2002, 22, 2054-2058. [CrossRef] [PubMed]

115. Matheson, N.R.; Wong, P.S.; Travis, J. Enzymatic inactivation of human alpha-1-proteinase inhibitor by neutrophil myeloperoxidase. Biochem. Biophys. Res. Commun. 1979, 88, 402-409. [CrossRef] 
116. Lomas, D.A. Polymerisation underlies alpha1-antitrypsin deficiency, dementia and other serpinopathies. Front. Biosci. 2004, 9, 2873. [CrossRef] [PubMed]

117. Ramirez-Alvarado, M. Amyloid Formation in Light Chain Amyloidosis. Curr. Top. Med. Chem. 2013, 12, 2523-2533. [CrossRef]

118. Bellotti, V.; Mangione, P.; Merlini, G. Review: Immunoglobulin Light Chain Amyloidosis—The Archetype of Structural and Pathogenic Variability. J. Struct. Biol. 2000, 130, 280-289. [CrossRef]

119. Benson, M.D.; Liepnieks, J.J.; Kluve-Beckerman, B. Hereditary systemic immunoglobulin light-chain amyloidosis. Blood 2015, 125, 3281-3286. [CrossRef]

120. Blancas-Mejia, L.M.; Misra, P.; Dick, C.J.; Cooper, S.A.; Redhage, K.R.; Bergman, M.R.; Jordan, T.L.; Maar, K.; Ramirez-Alvarado, M. Immunoglobulin light chain amyloid aggregation. Chem. Commun. 2018, 54, 10664-10674. [CrossRef]

121. Buxbaum, J.N. The systemic amyloidoses. Curr. Opin. Rheumatol. 2004, 16, 67-75. [CrossRef]

122. Nunan, J.; Small, D.H. Regulation of APP cleavage by alpha-, beta- and gamma-secretases. FEBS Lett. 2000, 483, 6-10. [CrossRef]

123. Gouras, G.K.; Olsson, T.T.; Hansson, O. $\beta$-amyloid Peptides and Amyloid Plaques in Alzheimer's Disease. Neurotherapeutics 2015, 12, 3-11. [CrossRef] [PubMed]

124. Glabe, C.G. Common mechanisms of amyloid oligomer pathogenesis in degenerative disease. Neurobiol. Aging 2006, 27, 570-575. [CrossRef] [PubMed]

125. Pearson, H.A.; Peers, C. Physiological roles for amyloid $\beta$ peptides. J. Physiol. 2006, 575, 5-10. [CrossRef] [PubMed]

126. Haass, C.; Selkoe, D.J. Cellular processing of beta-amyloid precursor protein and the genesis of amyloid beta-peptide. Cell 1993, 75, 1039-1042. [CrossRef]

127. Clarris, H.J.; Key, B.; Beyreuther, K.; Masters, C.L.; Small, D.H. Expression of the amyloid protein precursor of Alzheimer's disease in the developing rat olfactory system. Brain Res. Dev. Brain Res. 1995, 88, 87-95. [CrossRef]

128. Muresan, V.; Varvel, N.H.; Lamb, B.T.; Muresan, Z. The cleavage products of amyloid-beta precursor protein are sorted to distinct carrier vesicles that are independently transported within neurites. J. Neurosci. 2009, 29, 3565-3578. [CrossRef]

129. Cole, S.L.; Vassar, R. The Alzheimer's disease Beta-secretase enzyme, BACE1. Mol. Neurodegener. $2007,2,22$. [CrossRef]

130. Ando, Y.; Coelho, T.; Berk, J.L.; Cruz, M.W.; Ericzon, B.-G.; Ikeda, S.; Lewis, W.D.; Obici, L.; Planté-Bordeneuve, V.; Rapezzi, C.; et al. Guideline of transthyretin-related hereditary amyloidosis for clinicians. Orphanetj. Rare Dis. 2013, 8, 31. [CrossRef]

131. Kalkunte, S.S.; Neubeck, S.; Norris, W.E.; Cheng, S.-B.; Kostadinov, S.; Vu Hoang, D.; Ahmed, A.; von Eggeling, F.; Shaikh, Z.; Padbury, J.; et al. Transthyretin Is Dysregulated in Preeclampsia, and Its Native Form Prevents the Onset of Disease in a Preclinical Mouse Model. Am. J. Pathol. 2013, 183, 1425-1436. [CrossRef]

132. Kalkunte, S.; Boij, R.; Norris, W.; Friedman, J.; Lai, Z.; Kurtis, J.; Lim, K.-H.; Padbury, J.F.; Matthiesen, L.; Sharma, S. Sera from Preeclampsia Patients Elicit Symptoms of Human Disease in Mice and Provide a Basis for an in Vitro Predictive Assay. Am. J. Pathol. 2010, 177, 2387-2398. [CrossRef]

133. Wyatt, A.R.; Yerbury, J.J.; Ecroyd, H.; Wilson, M.R. Extracellular Chaperones and Proteostasis. Annu. Rev. Biochem. 2013, 82, 295-322. [CrossRef] [PubMed]

134. Humphreys, D.T.; Carver, J.A.; Easterbrook-Smith, S.B.; Wilson, M.R. Clusterin Has Chaperone-like Activity Similar to That of Small Heat Shock Proteins. J. Biol. Chem. 1999, 274, 6875-6881. [CrossRef] [PubMed]

135. Yerbury, J.J.; Poon, S.; Meehan, S.; Thompson, B.; Kumita, J.R.; Dobson, C.M.; Wilson, M.R. The extracellular chaperone clusterin influences amyloid formation and toxicity by interacting with prefibrillar structures. FASEB J. 2007, 21, 2312-2322. [CrossRef] [PubMed]

136. Yerbury, J.J.; Kumita, J.R.; Meehan, S.; Dobson, C.M.; Wilson, M.R. $\alpha 2$-Macroglobulin and Haptoglobin Suppress Amyloid Formation by Interacting with Prefibrillar Protein Species. J. Biol. Chem. 2009, 284, 4246-4254. [CrossRef] [PubMed]

137. Blacker, D.; Wilcox, M.A.; Laird, N.M.; Rodes, L.; Horvath, S.M.; Go, R.C.P.; Perry, R.; Watson, B.; Bassett, S.S.; McInnis, M.G.; et al. Alpha-2 macroglobulin is genetically associated with Alzheimer disease. Nat. Genet. 1998, 19, 357-360. [CrossRef] [PubMed] 
138. Ekelund, L.; Laurell, C.B. The pregnancy zone protein response during gestation: A metabolic challenge. Scand. J. Clin. Lab. Investig. 1994, 54, 623-629. [CrossRef]

139. Tatarinov, I.S.; Mesniankina, N.V.; Nikulina, D.M. Immunochemical indentification of beta globulin of the "pregnancy zone" in the blood serum of patients with hydatid mole and chorioepithelioma]. Akush. Ginekol. 1974, 5, 67-68.

140. Tatarinov, I.S.; Masiukevich, V.N.; Mesniankina, N.V.; Parfenova, L.F. Immunochemical identification of a new alpha 2 globulin in the blood serum of pregnant women]. Akush. Ginekol. 1970, 46, 25-28.

141. Perni, U.; Sison, C.; Sharma, V.; Helseth, G.; Hawfield, A.; Suthanthiran, M.; August, P. Angiogenic Factors in Superimposed Preeclampsia. Hypertension 2012, 59, 740-746. [CrossRef]

142. Rana, S.; Cerdeira, A.S.; Wenger, J.; Salahuddin, S.; Lim, K.-H.; Ralston, S.J.; Thadhani, R.I.; Karumanchi, S.A. Plasma Concentrations of Soluble Endoglin versus Standard Evaluation in Patients with Suspected Preeclampsia. PLoS ONE 2012, 7, e48259. [CrossRef]

143. Akolekar, R.; Syngelaki, A.; Poon, L.; Wright, D.; Nicolaides, K.H. Competing risks model in early screening for preeclampsia by biophysical and biochemical markers. Fetal Diagn. Ther. 2013, 33, 8-15. [CrossRef] [PubMed]

144. Sergeeva, V.A.; Zakharova, N.V.; Bugrova, A.E.; Starodubtseva, N.L.; Indeykina, M.I.; Kononikhin, A.S.; Frankevich, V.E.; Nikolaev, E.N. The high-resolution mass spectrometry study of the protein composition of amyloid-like urine aggregates associated with preeclampsia. Eur. J. Mass Spectrom. 2019, 146906671986007. [CrossRef] [PubMed]

145. Yakupova, E.I.; Bobyleva, L.G.; Vikhlyantsev, I.M.; Bobylev, A.G. Congo Red and amyloids: History and relationship. Biosci. Rep. 2019, 39, BSR20181415. [CrossRef] [PubMed]

146. Halimi, M.; Dayan-Amouyal, Y.; Kariv-Inbal, Z.; Friedman-Levi, Y.; Mayer-Sonnenfeld, T.; Gabizon, R. Prion urine comprises a glycosaminoglycan-light chain IgG complex that can be stained by Congo red. J. Virol. Methods 2006, 133, 205-210. [CrossRef]

147. Rood, K.M.; Buhimschi, C.S.; Dible, T.; Webster, S.; Zhao, G.; Samuels, P.; Buhimschi, I.A. Congo Red Dot Paper Test for Antenatal Triage and Rapid Identification of Preeclampsia. EClinicalMedicine 2019, 8, 47-56. [CrossRef]

(C) 2019 by the authors. Licensee MDPI, Basel, Switzerland. This article is an open access article distributed under the terms and conditions of the Creative Commons Attribution (CC BY) license (http://creativecommons.org/licenses/by/4.0/). 